\title{
The Dayton democracy model and its impact on the Bosnian State
}

\author{
Mahir Muharemovic \\ Faculty of Law-University of Tuzla, \\ Muhameda Hevaija-Uskufija 7, \\ 75000 Tuzla, Bosnia-Herzegovina, Balkan \\ Email: mahir85@gmail.com
}

\begin{abstract}
The Dayton Peace Agreement (DPA) ended the war in Bosnia-Herzegovina $(\mathrm{B} \& \mathrm{H})$ and created a new constitutional order. The very first unique feature of DPA is its 10th Annex which provides one person (The High Representative of the International Community in B\&H) with enormous powers (legislative, judicial and executive) which is granted to him by this Annex. In this respect a new concept of interventionism is introduced to justify the involvement of external factors in internal affairs of B\&H. The 'prescribed Dayton democracy' from outside is not really a democracy in a full sense, because it has put the war elites in charge, with a questionable legitimacy, who are under foreign influence. The DPA formalised and emphasised this concept of 'ethnicalisation' of the constitutional system, by putting the constituent peoples at the very core of Bosnian statehood. This constituent people's concept created an ethnic based power sharing that did not function until today. State-building in $\mathrm{B} \& \mathrm{H}$ has been drastically slowed down by internal disagreement, fostered by the consociatal model of democracy. Such 'constitutional and democracy model' impacts significantly the stability of the Bosnian state.
\end{abstract}

Keywords: veto players; extractive institutions; ethnocracy; consociational democracy;, rule of law; state institutions; Dayton Constitution; federalism; ethnic territories; ethnic voting.

Reference to this paper should be made as follows: Muharemovic, M. (2016) 'The Dayton democracy model and its impact on the Bosnian State', Int. J. Human Rights and Constitutional Studies, Vol. 4, No. 1, pp.45-53.

Biographical notes: Mahir Muharemovic is a Judge in a First Instance Court and holds an LL.M. in Public and International Law. He is also appointed as a Research Assistant at the Faculty of Law of the University of Tuzla.

\section{Introduction}

The Dayton Peace Agreement (hereinafter: DPA, agreed 21.11.1995 in Dayton and signed in Paris 14.12.1995.) as an international treaty, ended the war in BosniaHerzegovina (B\&H), which lasted from 1992-1995. The DPA was the result of the factual and emergency situation (the Realpolitik of the time), which created a new constitutional order, ignoring the previous one and without a real pouvoir constituent (Steiner and Ademovic, 2010). It rather represents a contract between the three ethnic 
communities in $\mathrm{B} \& \mathrm{H}$ with involvement of the international community and thus marks the 'ethnicalisation' of the constitutional order of B\&H (Sarčević, 2009). The very same character of the DPA implies that the constitution of B\&H, which is a part of the DPA as its Annex 4, has rather the qualities of an international treaty than a constitution (Constitutional Court of Bosnia-Herzegovina Decision, U 5/98) and that the Annex 4, as such, is subordinated to the international law. It seems to be a precedent in international law that international law establishes the constitutional order of a country like it is the case in B\&H. Nevertheless, the DPA provided some unique solutions that are raising concerns and are subject to critics which will be analysed in this article. Thus, key question is raised how this 'constitutional and democracy model' impacts state stability, or more precise, does this model lead to a more cohesive state or does it foster separatist movements.

The aim of this paper is to show how the existing normative order that prescribes democracy and on the other hand creates a 'weak' state, not bearing in mind the historical and social genesis of the modern Bosnian society, can have as a result a permanent instability of a state and its institutions. Furthermore, the contribution of this paper lies also in the attempt to show the complexity and the outcomes of state building by the international community. It depictures the deep damages an external intervention can cause by cementing and worsening a post-conflict situation by deepening institutionally division between ethnic groups in a multiethnic country creating so a weak and dysfunctional state.

This analysis shall have an interdisciplinary approach based on political science, law, history, sociology, anthropology and economy in order to explain the impact and the scope of the existing political and constitutional order on the society as a whole and its reflections on the state of $\mathrm{B} \& \mathrm{H}$. In this sense, empiric data related to the perception of the Bosnian population about the future of the Bosnian State will be collected. Primary sources will be used to draw a picture of the existing normative (constitutional) order in $\mathrm{B} \& \mathrm{H}$, but the research will mainly rely on secondary sources because of its interdisciplinary approach and scope.

The paper consists of three main parts dealing with the scope and depth of the influence of the international community on the institutions of $\mathrm{B} \& \mathrm{H}$, the concept of ethnic based power sharing and its reflections on decision making complexity, and finally, the causes of the phenomena of dysfunctional state institutions in B\&H.

\section{The influence of external factors on the Bosnian State}

The very first unique feature of DPA is its 10th Annex which provides one person (The High Representative of the International Community in B\&H) with enormous powers (legislative, judicial and executive) which is granted to him by this Annex. As the matter a fact the High Representative's duty is to take care of the civil implementation of the DPA. The relatively modest powers of the High Representative under Annex 10 were subsequently enlarged in practice by the Peace Implementation Council (PIC) a body with 55 members established to review progress regarding the peace settlement, in the decisions it took at the Bonn Summit of December 1997 (the Bonn Conclusions). These provided, for example, for measures to be taken against persons found by the High Representative to be in violation of legal commitments made under the Peace Agreement. 
This has included removal from public office, the competence to impose interim legislation where Bosnia's institutions had failed to do so [see more: Shawn, (2008), p.232].

In several decisions the Constitutional Court of B\&H stressed that it does not possess any authority to challenge the decisions of the High Representative because his authority is based on international law (Annex 10, Security Council of UN and the Bonn Declaration). As a matter of fact, these powers of the High Representative are the result of a consensus of the negotiating parties, primarily the ethnical groups, referred in the Annex 4 as constituent peoples, by which they voluntarily grant the High Representative sovereign powers (similar to the position Carl Schmitt defined as a person 'who decides on the exception') suspending so their own sovereign rights. This unusual structure with regard to an independent state arises, therefore, from a mix of the consent of the parties and binding Chapter VII activity by the Security Council. "The scope of the OHR is such that, to all intents and purposes, it constitutes the supreme institution vested with power in Bosnia and Herzegovina. In this connection, the Assembly considers it irreconcilable with democratic principles that the OHR should be able to take enforceable decisions without being accountable for them or obliged to justify their validity and without there being a legal remedy" [Parliamentary Assembly of the Council of Europe, (2004), p.2]. For these reasons, some authors regard Bosnia and Herzegovina as a protectorate without a stable and unquestionable statehood (Remenyi, 2012).

Besides the questionable legitimation of the DPA it also arises the question of the democratic legitimation of the powers who are vested in one person, The High Representative. It is obvious, as stated above, that his authority is based on international law and that he is not liable to any democratically legitimated institution of $\mathrm{B} \& \mathrm{H}$, but rather he represents the interests of the international community, embodied in the Peace Implementation Council (PIC), which appoints him and to which he answers (see more in: Chandler, 2000). All this seems to indicate that such constitutional order can be only provisional if we do not want to characterise such situation as undemocratic that poses a kind of international protectorate, bearing in mind that the external aspect of a state's sovereignty is its independence from foreign powers. "Although Bosnia remains formally a sovereign state, the extension of international mandates over the state has left little space for Bosnian state institutions to make or to implement policy" [Chandler, (2000), p.56]. In this respect a new concept of interventionism is introduced to justify the involvement of external factors in internal affairs of B\&H (Morrison, 1996). In this regard, the 'prescribed Dayton democracy' from outside is not really a democracy in a full sense, because it has put the war elites in charge, with a questionable legitimacy, who are under foreign influence (see more: Strasheim and Haßß, 2014). Such a situation makes the Bosnian State vulnerable to external factors, because the major global and regional powers are represented in the PIC (USA, Russia, Turkey et.al.) as the key players for the stabilisation or destabilisation of the Bosnian State. Although there are visibly less direct interventions by the international community in Bosnian affairs, the influence of external powers on internal affairs remains strong, as this influence is exercised now through the ethnic communities and the entities of B\&H. Traditionally, the Bosnian Serbs, as one of the constituent peoples of Bosnia (see explanation below) are supported by Russia, the Bosniaks by Turkey and the Bosnian Croats by the Western powers. 


\section{Ethnic based power sharing}

Another Dayton 'innovation' is the concept of Constituent Peoples, that was introduced through the Constitution of B\&H. The very term 'constituent' is derived from Latin. It might be translated as 'creative' or 'the one that creates/makes'. Constituent peoples therefore are those (peoples) that state's social quintessence is composed of. [Seizović, (2002), p.2]. The ethnic identities in B\&H are a social construct from the 19th century, generated by foreign forces, and were always instrumentalised by elites to foster conflicts between those identities (see more about the theory of ethnic identity and conflict in Schrader, 2012.) Prior to the dissolution of the former Socialist Federal Republic of Yugoslavia (SFRY) and its declaration of independence in 1992, the Republic of B\&H was one of the six republics of the SFRY. It was characterised by the highly diverse ethnic structure of its population (three peoples - Muslims, Serbs and Croats none of whom constitute an absolute majority, as well as 15 national minorities). "The war from 1992 until 1995 included 'ethnic cleansing' on a massive scale and the formation of ethnically homogenous territories. This ultimately led to a great number of crimes, including crimes against humanity, war crimes, crimes against a civilian population and genocide, all of which severely influenced the composition of Bosnia and Herzegovina's society" [Mujkić et al., (2008), p.2]. This new composition of population, mainly concentrated on single ethnic dominated territories, made the concept of constituent peoples the main concept of the all political, constitutional and social organisation, in the 'Dayton Bosnia and Herzegovina'.

Thus the constituent peoples concept will be the central problem to be analysed because of its wide reaching effects to the whole state system of B\&H. The fundaments of a such concept were laid down in the former socialist system [Mujkić, (2008), p.119], but the Annex 4 of the DPA formalised and emphasised this concept of 'ethnicalisation' of the constitutional system, by putting the constituent peoples at the very core of Bosnian statehood. According to the preamble of the Constitution "Bosniaks, Croats, and Serbs, as constituent peoples (along with Others), and citizens of Bosnia and Herzegovina hereby determine that the Constitution of Bosnia and Herzegovina is as follows" The direct results on relying on the constituent peoples principle are consociational characteristics of Bosnian democracy and the federalisation of its inner structure. Arend Ljiphart developed his theory of consociational democracy as an alternative model to majoritarian democracy. Ljiphart defines consociation by outlining eight identifiable structures that are all aimed at providing a more substantial form of proportional representation then typically found in a democracy. A consociaton must include

1 a grand coalition

2 a separation of powers

3 balanced bicameralism and minority representation

4 a multiparty system

5 a multidimensional party system

6 proportional representation

7 territorial and non-territorial federalism and decentralisation

8 a written constitution and minority veto [Galbraith, (2008), p.24]. 
All of these features are present in the 'Dayton order' of B\&H.

In the case of $\mathrm{B} \& \mathrm{H}$, both federalism and consociation are forms of non-majoritarian democratic governance that were selected at Dayton with the aim of mediating conflicts inherent to some degree in any pluralistic country. In order to reflect the consociational character of Bosnian society, grounded in the principle of constituent peoples, the DPA divided the territory of B\&H into two entities; The Republika Srpska (RS) and the Federation of Bosnia-Herzegovina (the Federation). The region that comprises the RS is primarily populated by ethnic Serbs, while the Federation is populated by a mixture of Croats and Bosniaks living in ten cantons. Five of the cantons are predominantly Bosniak, three are predominantly Croat, and the remaining two contain mixed populations. Some territorial units of the extremely decentralised state, where decision making and public and economic administration is focused on entity and cantonal level, have almost state-level rights, which are antagonistic to the integrity of the state as a whole [Remenyi, (2012), p.136]. This federal model represents a clear 'territorialisation' of ethnic principles that are derived from the constituent peoples notion granting so the relatively ethnic homogenous federal units high degree of autonomy. Such territorial division based on ethnicity deepens the gap of mutual mistrust between the constituent peoples and strengthens the entities and weakens the central government. Ethnic fear becomes the primary pattern of voters' behaviours in all ethnic groups leading to the absurd Prisoner's Dilemma situation forming so the continuous legitimation and power base for ethnic leaders and their parties [see more in: Evenson, (2009), p.97; Mujkić and Hulsey, 2010).

The political narrative and practice intended to justify this ethnically-based social construct is ethno-politics [Mujkić et al., (2008), p.17]. Thus the party system in B\&H is primary organised on ethnic rather than civic principles. Even parties claiming to represent the whole citizenry have only little or no support in all ethnic communities. Mostly their stem voters are from one ethnic community. The constitutional and electoral system of B\&H generates the need to form grand coalitions in order to have all the major ethnic parties represented in the government. Otherwise, the constitutional mechanisms granted to the entities and ethnic groups in the form of minority veto rights (in both chambers of the Parliament) could be and were used to block the whole state system. Even the government (Council of Ministers) and the Presidency of B\&H operate under this principles of entity-ethnic majorities and vetoes. The ethnic communities in B\&H do communicate on a political level only through their ethnic leaders which is a classic example of a consociation. This leads to a fragmentation of the Bosnian society and the development of an ethnic based identity and loyalty.

The constituent people's concept created an ethnic based power sharing that did not function until today. These circumstances make the presence of the international community inevitable. The state of $\mathrm{B} \& \mathrm{H}$ in its current form is kept together mainly by external forces, since among the internal forces the centrifugal ones (pulling states apart according to the model) overrule the centripetal ones (keeping states together). "Unless a state idea or raison d'être is developed, continuous external efforts are needed to provide relative stability" [Remenyi, (2012), p.130]. Paradoxically, the DPA seems to have established a constitutional and political order that facilitates ethnical tensions, divisions and disintegrations and that took away the sovereignty from the citizens of $\mathrm{B} \& \mathrm{H}$. To sum it up, the Dayton Constitution has just 'frozen' the conflict and transferred it into a legal and institutional framework. "The entire political structure of $\mathrm{B} \& \mathrm{H}$ is based on the 
principle of exclusive ethnic representation of the three 'constituent peoples', at the expense of individual rights" [Mujkić et al., (2008), p.14]. On the other hand, empirical data (Puhalo, 2009) show that the ethnic distance between members of the three constituent peoples is still big and that ethnic mistrust is still high. So it is not possible with this constitutional framework and social reality to create a Staatsvolk of B\&H that can be the source of sovereignty based on the civic model rather than on the ethnic model.

\section{Functioning under dysfunctional institutions}

In such situation the state of $\mathrm{B} \& \mathrm{H}$ is functioning barely with limited functions and capacity, because in its constitutional system there are too many 'veto players' build in. According to Tsebelis (2002), all institutional rules that delegate powers to different political actors within the system constitute potential veto points where individual veto players can block action by the whole body. These veto players have several constitutional mechanisms to block effectively every important reform, primary through the ethnic based 'vital national interest' veto, the 'entity vital interest' veto in the Presidency, the entity based voting in the lower house of the parliament etc. Such a deficit of state capacity results in weak institutions and therefore in a weak rule of law which is empirically evident through the Rule of Law Index (2014). In order to be effective and impersonal, states need to operate throughout law. But the law in B\&H is fragmented due to its federal structure (state level, entity level, cantonal level and municipality level) which is paying primary attribute to the ethnic based power sharing. There are also too many government layers that are potential veto players in the system. It is almost impossible to establish a legal reform from above to the bottom. The laws are often in contradiction with other laws on other levels, overlap with each other, they are unpredictable because of steady changes due to compromise based politics in a consociation, laws grant different rights to citizens in the same matter (a tipical example is that in B\&H exist four criminal codes and criminal procedure codes) depending which entity or canton issues such regulation. The judicial system is also highly fragmented (there are judicial institutions on the state level, entity/district and cantonal level with ten cantons) and the level of corruption is extremely high in the public institutions (see data from Corruption Perceptions Index of Transparency International for 2014, http://www.transparency.org/cpi2014/results). In addition to territorial administration, state administration is also highly decentralised. In order to prevent any of the former belligerents dominating the others, the so-called etnički ključ (ethnic key) has been reintroduced. This means that all of the public offices are filled with employees at the same ethnic rate as the ethnic composition of the respective territorial unit. This principle is used in the selection of public servants from the highest to the lowest territorial level of the state [Remenyi, (2012), p.134]. It should be stated that state institutions have only a small portion of competencies compared to the entities which leaves little space for those institutions to effectively influence key sectors in Bosnian society (e.g., education, social security, industry, agriculture). All this contributes to the weakening of the rule of law in $\mathrm{B} \& \mathrm{H}$.

The Dayton Constitution granted B\&H with a weak state and a democratic system that was based rather on ethnical than civic principles. "In the entities and cantons of 
$\mathrm{B} \& \mathrm{H}$ the power is in the hands of ethnocratic elites. This means that societal relations, accessing public goods, participating in decision making and advocating interests, and overall individual welfare and success are strongly dependent on ethno-territorial grounds" [Remenyi, (2012), p.136]. The result of this is the emergence of a clientelistic and patronage based democracy. Fukuyama (2014) explains that "clientelism emerges in young democracies precisely because the state and its resources constitute useful piggy banks for democratic politicians seeking to mobilise supporters." Exactly that happened in B\&H after democracy was introduced. Nationalistic parties, each claiming to represent one of the constituent peoples, took under their control all state resources, public institutions and companies. Jobs in state institutions and companies were reserved mainly for members of the ruling parties, their families and their supporters. This combination of clientelism and patronage resulted in an incompetent administration that is weakening the rule of law and directly weakens the economy in B\&H. Patronage and clientelism, as Fukuyama (2011) stated, represent the basic mode of sociality where altruism is based on kin or reciprocity. This 'basic mode' always strengthens in weak states with a weak rule of law. 'Filling' the institutions with people loyal to the parties rather than with qualified and moral one, who are dedicated to the state and the common good, results in 'privatisation' of the public sphere creating so, as Acemoglu and Robinson (2012) named it, 'extractive' institutions. These kind of institutions, empirically evident, harm the overall economy because they create an extractive economy functioning under political patronage and not under market principles. This situation, on the other side, supports the existing clientelistic and patronage based democracy in $\mathrm{B} \& \mathrm{H}$, because a relatively poor (see data from World Bank, 2015) population for European standards, mainly with little education (an UNESCO Research in 2012. showed a high percentage of illiteracy of 15\% in $\mathrm{B} \& \mathrm{H}$ and the functional illiteracy seems to be even higher) is likely to vote for those who can provide them with a stake in the existing system. On the other side, such a clientelistic state, which does not function according to the letter of law, produces a low trust society where the major population perceives the state as an enemy and thief and where the best solution is to avoid the state and to solve problems within the family, community or a private organisation. A similar situation occured also in Southern Italy leading to the emergence of the mafia. (see in Fukuyama, 2014.) This picture of a state is deeply rooted in the Bosnian society because of its historical experience (Ottoman Empire, Austro-Hungarian Empire, Kingdom of Yugoslavia and then socialist rule).

There is also another matter that follows state building, and that was not supported in the Dayton Constitution, the nation building. As mentioned before, the Dayton Constitutional Framework favours ethnic over the civic model, which is consequently enforced in the existing electoral model. But this model does not create the needed cohesion that would be necessary to have a functioning state. The state institutions are just 'prays' of the ethnic oligarchies, whereby these oligarchies, legitimated by their ethnic based mandates, use the state institutions to realise their particularistic ethnic interests.

All the above mentioned indicates that a weak Bosnian state hardly can generate the critical state capacity to effectively cope with the separatist ambitions of the Republika Srpska's government, backed by Russia, which on several occasions expressed the willingness to set on the agenda the question of a referendum dealing with the future status of RS within B\&H. 


\section{Conclusions}

It is obvious, from the previous analysis, that the Dayton democracy model does not function until today in a sense to create stabile and effective state institutions which would be capable to establish a real rule of law on the territory of $\mathrm{B} \& \mathrm{H}$, an economical framework that would foster growth and prosperity for all citizens, and to guarantee social security to all its citizens. Instead, this model introduced a consociational democracy favouring the three major ethnic groups, undermining so the concept of liberal democracy. Such consociational model has a major drawback, as Gray (2000, p.128) noticed, because such models are "often unstable and they do not survive for long unless they are underwritten by an external power." This is exactly the case in B\&H, where an ethnic homogenisation occurred during the war and created a long lasting segregated ethnic landscape which was formalised in the Dayton Constitution. Until today, as a result of that, ethnic tensions did not significantly and substantially decrease, but only remained in a 'frozen' state. Thus, state-building in B\&H has been drastically slowed down by internal disagreement, fostered by the consociatal model of democracy. In such situation, as Remenyi (2012, p.131) correctly analysed, "homogenous ethnic territories some of which are adjacent to 'mother nations' in neighbouring states - are strong centrifugal forces since they can form the territorial basis of ethno-territorial separatism." Furthermore, such system led to the creation of ethnocratic regimes that control virtually all public goods and constantly interfere in the free market creating monopoles under their control. Beside this, those ethnocratic regimes control almost every aspect of the public administration creating weak institutions which results in a weak state. This weak state is irreversibly incapable under these conditions to resist separatist movements within its territory.

Another question is if a new constitutional and political order, strengthening the central state weakening the ethnic based democracy model, would be beneficial to the overall social cohesion and would automatically lead to stronger central institutions. The author thinks that under this social realities it is utopian believe that a totally centralised Bosnian state is possible and that such forced model could function. A more modest but reformist approach is needed to resolve the Bosnian Gordian knot. This is where the international community still plays a vital role, because, as Remenyi (2012) noticed, there is no other choice for the international community but to support the integrity of the state, which also means that for as long as the centripetal forces do not out-weigh the centrifugal forces, energy should be invested into the system from external sources to keep it stable. This means that only under modest but effective pressure of the international community a constitutional and electoral system reform is possible which would partially eliminate some of the veto players within the institution of $\mathrm{B} \& \mathrm{H}$. Furthermore, a more radical judicial reform has to be implemented to strengthen the rule of law which could be one of the cohesive factors in Bosnian society. But, of course, such an engagement of the international community has to fit in the broader picture of international relations, which actually does not give an optimistic outlook.

\section{References}

Acemoglu, D. and Robinson, A.J. (2012) Why Nations Fail - The Origins of Power, Prosperity, and Poverty, Crown Business, New York. 
Chandler, D. (2000) Bosnia-Faking Democracy After Dayton, 2nd ed., Pluto Press, London.

Corruption Perceptions Index of Transparency International for 2014 [online] http://www.transparency.org/cpi2014/results (accessed 10 December 2015).

Evenson, K.D. (2009) 'Bosnia and Herzegovina statebuilding and democratization in the time of ethnic-politics and international oversight', Taiwan Journal of Democracy, Vol. 5, No.1, pp.93-125

Fukuyama, F. (2011) The Origins of Political Order-From Prehuman Times to the French Revolution, Farrar, Straus and Giroux, New York.

Fukuyama, F. (2014) Political Order and Political Decay- From the Industrial Revolution to the Globalization of Democracy, Farrar, Straus and Giroux, New York.

Galbraith, A.R.L. (2008) Bosnia-Herzegovina: Toward a Less Imperfect Union, Faculty of Wesleyan University, Middletown, Connecticut.

Gray, J. (2000) Two Faces of Liberalism, The New Press, New York.

Morrison, F.L. (1996) The Constitution of Bosnia-Herzegovina [online] http://conservancy.umn.edu/bitstream/handle/11299/167305/13_02_Morrison.pdf?sequence=1 \&isAllowed=y (accessed 25 January 2016).

Mujkić, A. (2008) We, The Citizens od Ethnopolis, Centar za ljudska prava Univerziteta u Sarajevu, Sarajevo.

Mujkić, A. and Hulsey, J. (2010) 'Explaining the success of nationalist parties in Bosnia and Herzegovina', Politička misao, Vol. 47, No. 2, pp.143-158.

Mujkić, A., Seizović, Z. and Abazović, D. (2008) 'The role of human and minority rights in the process of reconstruction and reconciliation for state and nation-building: Bosnia and Herzegovina', MIRICO: Human and Minority Rights in the Life Cycle of Ethnic Conflicts, Bozen.

Parliamentary Assembly of the Council of Europe (2004) Resolution 1384, Strasbourg.

Puhalo, S. (2009) Etnička distanca i (auto)stereotipi građana Bosne i Hercegovine, Friedrich Ebert Stiftung, Sarajevo.

Remenyi, P. (2012) 'The statehood of Bosnia-Herzegovina-according to the Hartshone model', Historia Actual Online, Vol. 7, No 27, pp 129-140

Rule of Law Index (2014) [online] http://data.worldjusticeproject.org/ (accessed 10 December 2015).

Sarčević, E (2009) Dayton Constitution - Characteristics and Characteristic Problems, Konrad Adenauer Stiftung, Sarajevo.

Schrader, L. (2012) Ethnopolitische Konflikte [online] http://www.bpb.de/internationales/weltweit/ innerstaatliche-konflikte/54504/ethnopolitische-konflikte, 10 February (accessed 20 December 2015).

Seizović, Z. (2002) Civil State and Concept of Constituent Peoples, Studio Flaš, Zenica.

Shawn, M. (2008), International Law, 6th ed., Cambridge University Press, Cambridge.

Steiner, C. and Ademovic, N. (2010) Constitution of Bosnia and Herzegovina - Commentary, Konrad Adenauer Stiftung, Sarajevo.

Strasheim, J. and Haßß, F. (2014) Demokratisierung [online] http://www.bpb.de/internationales/ weltweit/innerstaatliche-konflikte/54725/demokratisierung (accessed 24 December 2015).

Tsebelis, G. (2002) Veto Players: How Political Institutions Work, Princeton University Press, Princeton.

World Bank (2015) [online] http://data.worldbank.org/country/bosnia-and-herzegovina (accessed 10 December 2015). 